\title{
LOCALIZING JIHAD, GLOBALIZING JIMAT: BANSER AND JAMAAH MAIYAH IN A GLOBAL VILLAGE
}

\author{
AHMAD KARIM * \\ Amsterdam Institute for Social Science Research, \\ Dept. of Anthropology, University of Amsterdam
}

\section{Abstract}

During the last two decades, a dramatic transition from authoritarianism to a rapid process of democratization has been experienced by many different societies across the world. In Indonesia, reformasi 1998 has not only been followed by a massive transformation in many different dimensions but also the changing character of interdependently hybrid governance arrangements which lead to an 'authoritarian turn', particularly concerning about the visions of social harmony within a post-democratization context that is impacted by religious violent extremism. As such extremism is experienced daily in Indonesia and elsewhere in the world, while there is an absence of effective state interventions or at least the fact that state is no longer perceived as the principle referent for security, there has been an exceptional trend of what I call 'ref-ormas- $i$ '. It indicates how non-state actors, more specifically Ormas (mass organizations) is taking the shape of providing people's basic needs, professing security, promoting inter-religious tolerance, and even campaigning nationalism in the local, national, and global communities. This phenomenon certainly raises a question of how the non-state actors organize their role 'acting like a state' in society to produce new forms of 'imagined communities'. Based on

\footnotetext{
* Corresponding author: Amsterdam Roeterseilandcampus Building B-REC B 8.01 Nieuwe Achtergracht 166, 1018 WV Amsterdam Netherlands. E-mail: k.karim@uva. $\mathrm{nl}$.
} 
ethnographic fieldwork in two different Indonesian urban settings in Surabaya and Yogyakarta, this paper focuses on elaborating the roles of two different moderate Islamic groups, Banser and Jamaah Maiyah, more specifically on the discourses they use and the empirical actions they perform in securing the local community, defending the national ideology, and idealizing the global harmony through different interpretation of jihad and different approach of engagement in the society, more specifically for responding widespread religious extremism.

Selama dua dekade terakhir, transisi dramatis dari otoritarianisme ke proses demokratisasi yang cepat telah dialami oleh banyak masyarakat yang berbeda di seluruh dunia. Di Indonesia, reformasi 1998 tidak hanya diikuti oleh transformasi besar-besaran dalam banyak dimensi yang berbeda, tetapi juga perubahan karakter pengaturan tata kelola hibrida yang saling bergantung dan mengarah pada 'pergantian otoriter', khususnya mengenai visi harmoni sosial dalam sebuah konteks pasca demokratisasi yang dipengarubi oleh ekstremisme agama. Karena ekstremisme seperti itu dialami setiap hari di Indonesia dan di tempat lain di dun$i a$, sementara tidak ada intervensi negara yang efektif atau setidaknya fakta bahwa negara tidak lagi dianggap sebagai rujukan prinsip untuk keamanan, telab ada tren luar biasa dari apa yang saya sebut 'ref-ormas-i'. Ini menunjukkan bagaimana aktor-aktor non-negara, lebih khusus ormas (organisasi kemasyarakatan) mengambil bentuk menyediakan kebutuhan dasar masyarakat, menyatakan keamanan, mempromosikan toleransi antaragama, dan bahkan mengkampanyekan nasionalisme di komunitas lokal, nasional, dan global. Fenomena ini tentu menimbulkan pertanyaan tentang bagaimana aktor non-negara mengatur peran mereka 'bertindak seperti negara' dalam masyarakat untuk menghasilkan bentuk baru 'masyarakat yang dibayangkan'. Berdasarkan penelitian lapangan etnografi di dua kota di Indonesia, Surabaya dan Yogyakarta, makalah ini berfokus pada elaborasi peran dua kelompok Islam moderat yang berbeda, Banser dan Jamaah Maiyah. Lebih khusus penelitian ini mengamati wacana yang mereka gunakan dan tindakan empiris yang mereka lakukan dalam mengamankan komunitas lokal, mempertahankan ideologi nasional, dan men- 
gidealisasikan keharmonisan global melalui interpretasi jihad dan pendekatan yang berbeda dalam masyarakat, terutama dalam menanggapi ekstremisme agama yang tersebar luas.

Keywords: banser; democratic transition; jamaah maiyah; jihad; new imagined communities; non-state actors.

\section{Introduction}

"In Indonesia, religion seems to be a safe base for people to fall back on. People faced with pressing difficulties tend to seek security in their religion by relying more on their religious community, taking God more seriously and relearning their prayers. However, religion is not only a means of rescue in the private domain. Social problems and political troubles are often seen in relation to religious life" (Kleden 2003).

Kleden's premise seems to have a lot of empirical relevance considering that Indonesia is among the top three of the most religious countries in the world, after Bangladesh and Ethiopia, compared to the least religious countries of China, Sweden, and the United Kingdom (Gilani, Johnny, and Carballo 2018). Why is Indonesia so religious? Why is there such a high degree of religious extremists and religious related violent conflicts within religious communities in Indonesia, as compared to the other two most religious countries? Answering to these questions may need a comprehensive analysis on many different spectrums of Indonesian religious life because religion is complex and diverse, a multi-faceted phenomenon, including cognition, behavior, experience and more (Watts and Bretherton 2017).

Among many different definitions of extremism, Wildman (2011) suggests that extremism as "ideological beliefs and behaviors well beyond the boundaries of the 'normal' in a political, cultural, religious, or moral context", thus religious extremism can be seen as "...simply extremism when ideological beliefs are religious in nature and ideological behaviors 
are religiously motivated and rationalized". In this sense, understanding all aspects of religious extremism should be based on multiple dimensional perspectives, because historically and ethnographically studied from particular conflict situations have always shown that today's "moderates" become tomorrow's "radicals" and vice versa (Mietzner 2002).

The newest case of multiple suicide bombings killed hundreds people on Easter Sunday 2019 in Srilanka carried out by mostly educated and middle-class backgrounds provides a clear example. Other incidents of the brutal mosques shooting in Christchurch, New Zealand done by a 'normal' young man, the suicide bombings at three churches in Surabaya by a single 'ordinary' family of six in May 2018, or the earlier case of Triyono Ut tomo Abdul Bakti, an ex-government officer at the Ministry of Finance who held a Master's degree from the University of Adelaide, Australia and brought his family to join ISIS in Syria but then deported by Turkish authorities in 2017, and also the case of Fadlullah Hasan (a Bali bomber 2012 and a close friend of Noor Huda Ismail, a journalist and anti-terrorist activist), are just fiew examples illustrating how ordinary citizens easily turned out towards the circles of extreme violent religious extremism.

In the context of Indonesia, due to the fact that postauthoritarian era has not only been characterized by series of ethnic and religious conflicts, but also with multiple globally recognized terrorist attacks and undeniable cases of identified Indonesian Muslim jihadists joining ISIS. ${ }^{2}$ This local-global connectedness of religious extremism creates the story of security discourses and practices for what Abrahamsen and Williams (2009, 3) describe as 'global security assemblages',

${ }^{2}$ Setyo Wasisto, the head of Public Relation of the National Police revealed to KOMPAS, September 20, 2017 that there were 671 Indonesian Muslims (including 147 women) identified to join ISIS in Syria and Iraq. 
which are defined as "settings where a range of different global and local, public and private security agents and normativity interact, cooperate and compete to produce new institutions, practices, and forms of security governance". This perspective is crucial in the sense that the 9/11 tragedy, which is seemed to bring about a public consensus that "everything had changed" (Lipschutz 2009) for the global security sphere. In this respect, it is impossible for state actors to provide all security solutions without active roles being played by non-state actors, more specifically given the fact that Indonesian security spaces are defined by contestation (Wilson 2017), rather than by effective state's rule of law.

Geertz (1996), for example, illustrates this complication with an idea of "religion as a cultural system". This has complicated symbolic interpretations, in the sense that symbols can help people feel safe and comfortable, but at the same time also trigger memories of trauma (Schirch 2015). While, Hefner (2013) comes up with the idea that religion in Indonesia has highly influenced by what he calls the "zig-zag shifts of the country's politics". Within these considerations, it is important to note that Indonesian society has experienced hundreds of years of pressing difficulties under the Dutch colonial rule, years of turmoil in the political situation between communists, nationalists, and religious groups during the Old Order regime, three decades of the pressure of dictatorship during the New Order era, and the bloody May 1998 reform tragedy that paved new democratic transition. The Indonesian post-authoritarian era provides a good illustration of a rapid process of democratization marked with increasing proliferation of massive ethnic-religious violent incidents and conflicts. This has led to the emergence and the development of a wide variety of non-state actors, more specifically religious militia and civil vigilante groups claiming public authority 
through the provision of security services as a public good (Bakker 2015; Telle 2013; Wilson 2017).

Then, the democratic transition has also brought a dilemmatic situation to the state security forces (TNI and POLRI) because on the one side they had lost credibility in providing security due to a long history of becoming more of a political institution rather than a defense force. On the other side, they had to struggle with new security threats (extremist groups and terrorists), due to the fact that Indonesia is considered as both a battlefield of a global terrorist movement, and as a "producer" of terrorists. As a result, after two decades of post-authoritarian rule, Indonesia has not only been characterized as a 'contested arena' of (un) civil society and political change (Beittinger-Lee 2010) and as a 'contest state' of institutional configuration of power (Nordholt 2016), but also as a contested security space derived from the everyday politics of Indonesian people's lives (Wilson 2017). In many cases, as Bakker (2015) has noted, the national military force and police usually play minor roles in preventing or putting down regional violence, so that local inhabitants must come up with their own solutions and strategies to cure the development and settlement of religious related violent incidents and conflicts.

In responding to the absence of effective state interventions, there has been a dramatically growing number of social and religious movements performing their own initiatives that are more globally recognized in deploying defense, policing people, offering governance and development activities to counter extremist violence (Denney 2012; Krause 2013). According to Bayat (2005), the defining feature of a social movement is a unity of purpose and action, where "shared interests and values are invariably proposed to account for the elements which bring actors together for a united purpose". When these kinds of united purposes are very diverse, as reflected in post-reform 
Indonesian society and elsewhere in the world, even though the movements are coming from similar Islamic ideologically driven backgrounds, those who do extraordinary things will get more attention, and that is what has been done by the religious extremist groups. Obtaining greater attention means an escalating chance of getting larger numbers of sympathizers and followers.

Among many different religious groups, Banser and Jamaah Maiyah are moderate Muslim groups that have been extraordinarily shown their empirical engagements in securing the local community, defending the national ideology, and idealizing and promoting the global harmony, particularly through different interpretation of jihad and different approach of engagement in the society for responding wide-spread religious extremism. These two different groups, with different orientations, help explain what Hefner (2013) has emphasized that Indonesia's Islamic reform movement has played an exceptional role in challenging stereotypes of Islam as antagonistic to democracy and rejecting the goal of an Islamic state, as well as promoting democratic ideals and women's rights, and mobilizing religiously ecumenical support.

Banser and Jamaah Maiyah: Singing to a Similar Rhyme, Dancing to a Different Drum

Banser, of which Beittinger-Lee $(2010,159)$ has difficulty in classifying this group into what she calls "Uncivil Society Organizations" (USOs), is a Muslim paramilitary group with a long historical root in the Islamic movement as well as Indonesian independence movement. It belongs to Gerakan Pemuda (GP) Ansor (Ansor youth movement), a youth wing of the Nahdlatul Ulama (NU, the biggest Indonesian Muslim organization established in 1926 in Surabaya, East Java by a charismatic moderate Muslim ulama named K.H. Hasyim Asy'ari as a 
response to the rise of Wahabism in the Arabs). The name Banser comes from an Indonesian acronym of Barisan Ansor Serbaguna (Ansor's multipurpose troops). Barisan (n) literally means front, troops, squad; while Ansor (n) means "helper", welcomer, host; and Serbaguna (adj) means multipurpose, versatile.

Anam (1996) notes that the initial name of GP Ansor was Anshoru Nabdlatul Oelama (ANO), established during the $9^{\text {th }}$ NU Congress in Banyuwangi, East Java on April 24, 1934, the offcial date of birth of GP which has just celebrated 85 years of anniversary). During the second congress of ANO in 1937, initiated by $\mathrm{KH}$. Abdul Wahab, ANO created Barisan Ansor Nabdlatul Oelama (BANOE), consisting of a youth group of civil militias, as part of NU's contribution to the process of the independence revolution movement against Dutch colonial rule, which was then also strengthened with Resolusi Jihad Fì Sabilillāh (NU's jihad resolution) on October 22, 1945 in Surabaya. The first commander of BANOE was Syamsul Islam, who was also the chairman of the ANO Malang (East Java) chapter under the advisory of the Indonesia National Armed Forces (TNI) commander Hamid Rusydi. The name of ANO was then transformed into GP Ansor on December 14, 1949, and this name still exists today. Since its initial establishment, $B A N O E$ has had a very close relation with TNI. This is not only because the group played a key role in supporting TNI during the independence revolution, but also as a matter of fact that its total members compared to the number TNI personnel ( 5 million of Banser members vs less than 1 million personnel of TNI). In the beginning of 1960 s, as a response to frequent confrontations with the PKI (the left-wing party) and its affiliated organization of Barisan Tani Indonesia (Indonesian Peasant Front), the name Banser was officially used, and Mohammad Zainuddin Kayubi was appointed to be the first commander. The tension between 
NU and PKI reached its height during the mass killings of 19651966 against the recognized members of PKI. TNI and Banser played major roles in this moment of historical violence (La Botz 2001, 248).

Throughout Suharto's New Order era, the relation between Banser and the state was up and down, even though there was no serious confrontation. Banser was mainly used for the political purposes of NU under the vehicle of the United Development Party (PPP), the opponent of Golkar's government party. During the era of early 1980s (in the 1983 NU's national meeting in Situbondo, East Java), NU decided to withdraw from its political activities and moved 'back to khittah' or back to the original 1926 fundamentals of socio-religious concerns, with a commitment to support the national ideology of Pancasila. Since then, as Banser has become a more autonomous organization without direct orders from NU as it previously had. Then, it has become a main collaborator with TNI for a wide range of military trainings and security activities (Salim 2004). Banser has memoranda of understandings (MoU's) to strengthen its authority, not only with TNI, but also with Konperensi Waligereja Indonesia/KWI (Bishops' Conference of Indonesia) and other state and nonstate elements, to mobilize massive armed forces for security purposes, as well as social, political, and business-related goals, and more importantly for fighting against other Islamic groups trying to replace the national ideology of Pancasila.

Ontologically, based on an interview with senior member of GP Ansor in East Java, the spirit of the GP Ansor religious movement was inspired by the moment of hijrah (migration) of the prophet Muhammad in Islamic history. The word ansor refers to a group of local inhabitants of the city of Medina who welcomed and provided shelter, foods, and other needs of the immigrants from Mecca (known as muhäjirin) who followed the 
migration of the prophet. By using Banser as the core cadre of GP Ansor, it has an idealization of what it is commonly perceived in Indonesia as Masyarakat Madani (the word madani comes from Medina, civil society based on the revitalization of Islamic values and local tradition by the prophet in the city of Medina). As symbolized in the logo of Banser, the pentagonal shape indicates the five pillars of Islam and Pancasila as the five pillars of Indonesian state. The bird's wings refer to Abābill (the bird of Mecca), a miraculous bird (identified as swallows) mentioned in the Quran that protected the Ka'ba in Mecca from the Aksumite elephant army of Abraha in the year of 570. The Arabic words of nabnu anshärullāh mean "we are the saviors" or "we are the rescuers", indicating a commitment to 'protect', or to 'ensure security'. A symbol of the "fighting knife" represents "readiness for fighting" and explicitly promotes physical power and violence as the main tools of Banser for its security provision.

\section{Figure 1}

Official Symbol of Banser

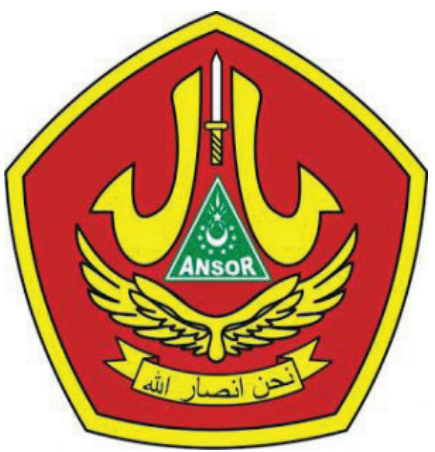

Source: nu.or.id, 2019

As a state registered legal mass organization under Indonesian Ormas Law, Banser has many different sources of funding, but mostly gathered from NU-affiliated crowdfunding resources. For social purposes, they are securing religious events, provide 
personnel for disaster related incidents, and work together with police and military forces during social conflicts or mass violence. The membership consists of predominantly the low income and low educated population coming from rural areas, such as: agricultural workers, peasants, truck and ojek drivers, and other informal workers, while a large number of them are unemployed citizens. Currently, there are also a growing number of educated people joining this group with a wide variety of reasons. Among these population, Rudiyanto (pseudonym), a university graduate from Surabaya represents common reason by revealing;

"I am interested in joining Banser simply because it has been consistently standing in the forefront of struggles against any groups trying to replace Pancasila with other national ideology...I was personally called to protect NKRI (the Unitary Republic of Indonesia), as mandated by ulama and the founding fathers of Indonesia, without expecting material rewards" (interview with Rudiyanto, November 10, 2018).

Interestingly, it is very common for the new members of Banser to use their own money to buy a military-like uniform which is required to be used for all its related activities. In many cases, they have to borrow money from their relatives or friends in order to make sure that they can be immediately on duty right after finishing Banser's basic training. In operationalizing its religious movement, Banser has at least eight divisions, with each own different role, as listed in table 1 below.

Table 1

Divisions of Banser

\begin{tabular}{cll}
\hline No. & \multicolumn{1}{c}{ Name of Divisions } & \multicolumn{1}{c}{ Main Function } \\
\hline 1. & $\begin{array}{l}\text { Densus 99 (Detasemen Khusus } \\
99 \text { Asmaul Husana): Special } \\
\text { detachment 99 }\end{array}$ & $\begin{array}{l}\text { security guards for religious and social } \\
\text { activities }\end{array}$ \\
\hline 2. & $\begin{array}{l}\text { Bagana (Banser Tanggap } \\
\text { Bencana): Disaster response unit }\end{array}$ & $\begin{array}{l}\text { disaster prevention, emergency } \\
\text { response and rehabilitation. }\end{array}$ \\
\hline
\end{tabular}




\begin{tabular}{cll}
\hline 3. & $\begin{array}{l}\text { Balakar (Banser Penanggulangan } \\
\text { Kebakaran): Firefighters' unit }\end{array}$ & $\begin{array}{l}\text { prevention of fire hazards, emergency } \\
\text { response, and rehabilitation }\end{array}$ \\
\hline 4. & $\begin{array}{l}\text { Balantas (Banser Lalu Lintas): } \\
\text { Traffic force }\end{array}$ & $\begin{array}{l}\text { traffic handling, and transportation } \\
\text { issues, as well as reducing accident } \\
\text { risk }\end{array}$ \\
\hline 5. & Basada (Banser Husada): & $\begin{array}{l}\text { humanitarian assistance medical } \\
\text { issues, health, and promoting healthy } \\
\text { living norms for society }\end{array}$ \\
& Health aid troops & $\begin{array}{l}\text { State-related event management, } \\
\text { official NU organizations or events }\end{array}$ \\
\hline 6. & $\begin{array}{l}\text { Protokoler (Banser Protokoler) } \\
\text { Official Strikebreaking force }\end{array}$ & $\begin{array}{l}\text { safeguarding, preserving, and } \\
\text { conserving the maritime region }\end{array}$ \\
\hline 7. & $\begin{array}{l}\text { Baritim (Banser Maritim): Navy } \\
\text { troops }\end{array}$ & $\begin{array}{l}\text { observing, supervising, controlling, } \\
\text { cracking down, evaluating and } \\
\text { punishing forces within the internal } \\
\text { organization }\end{array}$ \\
\hline 8. & $\begin{array}{l}\text { CPB (Corp Provost Banser): } \\
\text { Elite corps }\end{array}$ &
\end{tabular}

Source: Juklak Banser (Banser's guide book), Satkornas (National coordinating board), 2017.

Nowadays, with an estimated membership reaches more than 5 million squads nationally, three to five times bigger than the total number of TNI personnel (Indonesian state armed force) and POLRI (the national police) combined (even the national office of GP Ansor has no actual data on the real number of Banser members), Banser has even more roles than its original goals at its establishment. In many regions, especially in East Java, it has shown more progressive roles and initiatives in response to the issue of radicalism and terrorism, including persistent confrontations with radical Islam groups. The case of Riyanto, a heroic Banser member, who sacrificed himself and died in a Christmas Eve bomb blast in 2000 in Mojokerto (East Java) protecting many Christians' lives, was also an example of how first-hand and immediate security in the field can be performed by Banser at any given period of time or location throughout the country. Kastkorcab (city commander) of Banser in Surabaya revealed that he has serious and long process of investigation as a witness of the 2018 surabaya bombings, a series of attacts occurred on May 13 in three churches. 
“...it is actually draining my mind and energy, but after all, I have to help protect my city and my country from terrorist threats and those who claim jihad to replace Pancasila with khilafah" (interview with Kasatkorcab Banser Surabaya, November 15,2018 ).

Last year, the incident of alleged HTI's flag burning by Banser members in West Java last year, which raised national controversy, showed how this group tried to convince public that they are really on the front row for "fighting" against what they call the suporters of khilafahism. For the last couple of years, dozens of international branches of NU around the world have been trying to established GP Ansor and Banser to support their global engagemant in countering religious extremism. International basic trainings of Banser have also been successfully organized in five different countries, which are Saudi Arabia, Taiwan, South Korea, Malaysia, and Egypt with high enthusiasm.

Jamaah Maiyah. Literally, Jamaah (Arabic: jamāa $a h$ ) means doing things together, but the Indonesian translation has slightly different meanings: Jamak (adj) means plural, more than one; jamaah (n) means group of people, ber-jamaah (v) means get together or in congregation; and Maiyah (Arabic: $m \bar{a}$ ' $a$ ) means with-, $m \bar{a}$ 'ana means with us; $m \bar{a}$ 'allah means with Allah/God; Maiyah can be interpreted as togetherness, because it has no Indonesian term. Semantically, it has underlying cognition of the concept of Maiyah, which refers to a powerful sense of communion and togetherness (Daniels 2009, 136). It was originally a small traditional monthly pengajian (religious gathering) initiated in October 1993 by Emha Ainun Nadjib (Cak Nun) and his family, named Padhangbulan (full moon) as it is usually held on the $15^{\text {th }}$ of the Islamic calendar (the middle of the month), in Jombang, East Java, which led to regular gatherings in many different places with each local name. 
Kamba (2015) pointed out that the term Maiyah is also based on the sayings of Prophet Muhammad to his friend Abu Bakar in the cave of Tsur during the moment of Hijrah (migration from Mecca to Medina), when they were surrounded by their enemies: "...là tahzan, innallāha ma'anā..." ('Don't be sad, indeed Allah is with us', and Allah sent down his tranquility upon him and supported him with angels you did not see ..." (al-Quran, al-Taubah 9:40). In this case, Betts (2006) has called Maiyah the jalan sunyi Emha (the silent pilgrimage of Emha) to illustrate how the group is looking for a new pathway as a socio-cultural as well as religious movement. The moving (migration, transformation) is what is important from the moment of Hijrah in Islam, as Maiyah also uses its spirit, rather than the moment of the date of birth of the prophet. That is why Islamic calendar is started from this moment (unlike the calendar in Christianity, Buddhism, Hinduism, and others that use the birthday or the death day of founders). Kamba (2018) also argues that Maiyah is jalan kenabian (a prophetic pathway) based on five main principles: kemandirian (sovereignty), kesucian (purity), kebijaksanaan (wisdom), kejujuran (honesty), and cinta kasih (love). The term Maiyah was officially used in July 1998, especially right after the reform movement, when Cak Nun played important roles in convincing Suharto to resign, and in preventing wider riots in Jakarta and other cities. This included Yogyakarta, where he was one of the most vocal figures during the series of protests against the New Order regime. Maiyah, as Cak Nun has frequently asserted in different Maiyah gatherings, was initially a form of social and political critique from Cak Nun in response to what he considered 'pengkhianatan agenda reformasi' (the violation of the reform agenda). In this context, the majority of Muslim intellectuals and prominent political leaders, including Cak Nun, were at 
first engaged in the Indonesian reform processes and agreed to work together in establishing komite reformasi (a specific team of reform commissioners) for the preparation of the political transition after the resignation of Suharto. However, most of these leaders then found their own agenda of establishing their own political parties and organizations, and simply aimed to get the highest position in the new political arena. Cak Nun has often illustrated this concern with a dialogue between Gusdur and Soeharto:

Gusdur : Pak Harto, do you know that you're really missed by most of Indonesian people?

Soeharto: Are you sure, Gus? How can you say so?

Gusdur : When I try to see a current situation of my hometown, Jombang, with a permission from Malaikat, I always find an interesting image of your smiling face in the backside of many trucks passing by my pondok pesantren with a specific saying: "Enak Jamanku tho?" (more comfortable during my era, isn't it?)

Soeharto: So, do you agree with that Gus?

Gusdur : Oh...of course Pak Harto. You know, during your era, you're the only Soeharto. But now, everybody has become Soeharto.

As a result, a new Indonesian democracy, based on its historicity and socio-cultural wisdom as imagined by Cak Nun and other 'early figures of reform' have never been discussed and manifested. In this context, the "American democratic style" (secular and capitalist system) has then taken for granted by the later reformist figures in affiliation with their own groups and political parties. Cak Nun considers that this "violation" of the reform goals, can also be interpreted as a violationof the core values of Pancasila, in which the first pillar is belief in God 
in monotheistic terms, and other pillars are all connected. The only solution to treat and 'medicate' this violation, as Cak Nun has always emphasized and as is noted by Sumuranje (2013), was taqwa (God-fearing), through what Cak Nun called Cinta Segitiga Maiyah: melamar Syafaat Rosulullah (the triangle of love: proposing the blessings of the prophet). This is why he also refers to Maiyah as a form of gerakan șalawat (șalawat movement), simply suggesting that all human activities (politics, economics, religion, and socio-cultural issues) should be based on the spiritual values of God's rule of law, through what has been exemplified by the prophet Muhammad. In local Javanese term, Cak Nun uses a phrase:

"Maiyah is a training process of how we learn together, gondelan klambine Kanjeng Nabi (holding on the prophet's vestment" (Cak Nun, Mocopat Syafaat, October 2018).

In putting forward the idea of transformation, a șalawat movement is then considered a mode of reminder, suggesting that the prophet has given a way of thinking that should be seriously learned by all Muslims, as the only way to reach God is through the prophet. Cak Nun himself, on many occasions, describes this Maiyah triangle of love can be applied to any issues in the world, including dealing with religious conflicts, violence, and other harsh situations. Interestingly, this principle can also be found in the work of American psychologist Sternberg (1988), The Triangle Theory of Love, suggesting that the love relationship should be based on three main components: intimacy (feelings of closeness, connectedness, and bondedness); passion (the drives that lead to physical attraction); and commitment (a decision that one loves a certain other and to maintain it). Maiyah, in some degrees, is all about applying this way of thinking. 
Figure 2

Maiyah Triangle of Love. Notes: "Maiyah Triangle of Love" (right), putting spirituality (God and the Prophet) as the main orientation of life (individual sovereignty is outside the world's circles), instead of world's materiality (left) that drives all life's orientation (so that individual sovereignty is under the control of world's circles).

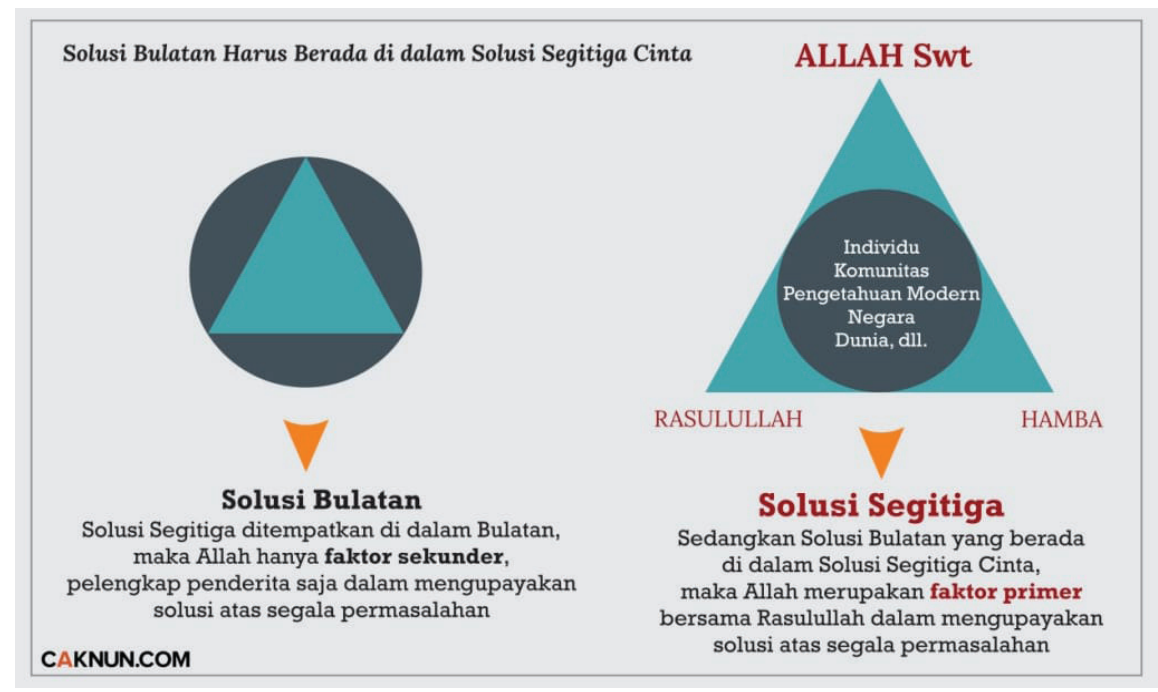

Source: caknun.com, 2018.

Without a clear distinction between the roles and the depositions of the state (a nation state) and the government (political entities), what is being created for the future Indonesia, as Nadjib (2016) has assumed, is destruction, the ruin of the society. Therefore, in order to prevent the worst impacts and immediate destruction, Cak Nun initiated șalawat movement along with Kiakanjeng, a Gamelan fusion orchestra, a combination between Javanese traditional musical instruments and Western as well as Mediterranean musical instruments, as the main media of the șalawat movement. Using this approach, compared to other identical groups (Salafi, Tarbiyah, Jamaah Tabligh) and considering that Jamaah Maiyah is a relatively new group which has both features of sufism and social and 
political activism at the same time, it has been successful in terms of pengajian lintas agama and lintas budaya (interfaith or inter-religious and cross culture dialogue), established after the reform era with participants from multi-religious and social backgrounds (Widiyanto 2016, 67), and has promoted different 'taste' of Islam across the world during his international tour with Kiaikanjeng in many different countries. Maman (Pseudonym), a routine participant of Jamaah Maiyah gatherings in Yogyakarta, revealed:

"I feel comfortable with Maiyah community because it does not dictate me, it does not push me to behave or to do or not to do anything like ormas or other formal institutionalized organizations, but it does train me how to decide to do things." (Interview with Maman, July 12, 2018). Currently, there are two different Maiyah forums: Maiyahan (a regular monthly gathering with Cak Nun or other activists within 'internal' Maiyah circles) and Sinau Bareng (gatherings with Cak Nun and Kiaikanjeng consists of religious preaching, discussion, workshop, and musical performance intended to wider audiences across the country). The five main regular monthly Maiyah forums and Sinau Bareng usually gather thousands of participants in each event. Since 2011, there have been more than 70 'official' Simpul Maiyah (Maiyah 'branches' nationally and internationally with a responsibility to have a coordination mechanism with Maiyah Kadipiro office in Yogyakarta) and hundreds Lingkar Maiyah (Maiyah smaller circles) that are established indepedently throughout Indonesia and in many other countries. Interestingly, the name they use usually represents local knowledge and the spirit of looking for 'local soveregnty' by combining Islamic values and local cultural believes in deconstructive ways, such as Obor Ilahi in Malang, Paseban Majapahit in Mojokerto, Sanggar Kedirian in Kediri (East Java), Kidung Sayafaat in Salatiga, Sabamaiya in Wonosobo, Juguran Syafaat in Banyumas (Central Java), Jamparing Asih in Bandung, Lingkar Daulat Malaya in Tasikmalaya, Pameungkeut Asih in Subang (West Java), Ambengan in Lampung (Sumatera), Cangkir Syafaat in Central Kalimantan, Syafaat Batang 
Banyu in South Kalimantan, Masuisani in Bali, Papperandang Ate in West Sulawesi, Tongil Qoryah in South Korea, Mafaza in Europe, and many other names.

Table 2

Jamaah Maiyah Main Gatherings

\begin{tabular}{llll}
\hline Name of Events & \multicolumn{1}{c}{ Location } & \multicolumn{1}{c}{ Schedule } & Initiation \\
\hline Padhangmbulan & $\begin{array}{l}\text { Jombang, East } \\
\text { Java }\end{array}$ & $\begin{array}{l}\text { Every } 15^{\text {th }} \text { of } \\
\text { Javanese calendar }\end{array}$ & Started 1993 \\
\hline Mocopat Syafaat & Yogyakarta & Every 17th month & Started 1998 \\
\hline Gambang Syafaat & $\begin{array}{l}\text { Semarang, } \\
\text { Central Java }\end{array}$ & Every 25 $5^{\text {th }} /$ month & Started 1999 \\
\hline Kenduri Cinta & Jakarta & $\begin{array}{l}\text { Friday, the 2 } \\
\text { month }\end{array}$ & Started 2000 \\
\hline Bangbang Wetan & $\begin{array}{l}\text { Surabaya, East } \\
\text { Java }\end{array}$ & $\begin{array}{l}\text { A day after } \\
\text { Padhangmbulan }\end{array}$ & Started 2006 \\
\hline
\end{tabular}

Source: caknun.com, 2019

What is also interesting in terms of building a sense of security in the local community is that at almost all the events or performances by Kiaikanjeng that are at the invitation of the local community, there are a "triangle of security figures" on the stage (Cak Nun, the city mayor, and the chief of local police and the army commander) performing șalawat together. They claim that all the Maiyah events, usually running from 8 o'clock at night until 3 or 40 'clock in the morning, do not require security forces because the security forces themselves prefer to join to the rhythm and the spiritual atmosphere they create together during the night's events of music, dialogue, discussion, speech, jokes, poetry reading, drama, recitation of religious texts, and other syncretized religious-cultural 'rituals' based on a simple triangle concept of security Iman-Aman-Amin (faith-security-blessings). 


\section{Localizing Jihad, Globalizing Jimat}

What does jihad mean? As the last two decades of global security discourses have seen wide ranging references of jihad, more specifically after the 9/11 tragedy which led to the overrepresented of such word in the Western news media, and in practice there has been so much use of the expressions of jihad in Islam's political movements referring to a commitment to the spread of Islam through the 'holy war' or jihadist attacks, it is important to note that the interpretation of jihad is very diverse and should be seen in local contexts. Banser and Jamaah Maiyah, in this case, offer distinctive interpretations of jihad both in a discourse of nationalism and empirical engagement they perform within local, national, and global community.

For Banser, the narrative of jihad has a high degree of its original meaning as 'struggle' or 'striving' of doing things in the way of God and even still has retained its religious and military association, but it is also having broader dimensions in their activism. It refers to the founding father of $\mathrm{NU}, \mathrm{KH}$ Hasyim As'ari (April 10, 1875-July 25, 1947) who initiated and declared Jihād Fì Sabilillāh Resolution 1945 during the Indonesian independence revolution against the Dutch colonial. This spirit, as it is then nationally commemorated as a Hari Santri Nasional (national santri day) by Presidential Decree signed by President Joko Widodo in 2015, finds its relevance in the period of the rise of terrorism, violent religious extremism, and massive efforts of 'khilafahism' (establishing Islamic state) across the globe that are also utilizing the narrative of Islamic jihad. In the local Indonesian context, as khilafahism has many different features, what has been done by Banser and its affiliated organizations was pushing the state to close down any potentiality of religious movement that has a mission for establishing Islamic state. The banning of Hizbut Tahrir Indonesia (HTI) by the government 
in 2017 was one accomplished missions through constitutional channels, but there are many other threats of underground movements threatening NKRI (the Indonesian state), Pancasila and Bhinneka Tunggal Ika (the two main national doctrines) that $\mathrm{KH}$ Hasyim As'ari ordered younger generations of NU, including Banser to defend them using the spirit of NU's Jihad resolution.

This spirit is also manifested in the daily activities of Banser called ngepam (providing security provision) through eight main divisions as above mentioned. Based on my interview with Banser members, one of the main reasons why they are joining this group is that, Banser offers an opportunity to follow KH Hasyim As'ari's pathway to do jihad and more importantly it gives a status of becoming santri of Mbah Hasyim even though they are not spending a period of time studying in pesantren (Indonesian Islamic traditional boarding school), as they do not have opportunity and capacity to do so. In this context, Kyai Hasyim Asy'ari, has been highly recognized with his clear 'genealogy' of Islamic knowledge and his contribution to synthesize Islam and nationalism within one breath. Therefore, following Mbah Hasyim also means following the prophet Muhammad, a strong believe among Banser members for securing a 'ticket' to Jannah (paradise), not only for them, but also for their families. One of the famous testaments from Kyai Hasyim Asy'ari which is used by all Nabdliyin (NU followers including Banser) as a source of inspiration or motivation for joining Banser is:

"Barang siapa yang mau mengurusi NU, saya anggap ia santriku. Siapa yang jadi santriku, saya doakan khusnul khotimah beserta anak cucunya" (Whoever wants to take care of NU, I consider him to be my santri. For those who do so, I beg to God for their good life and for all of their next generations).

Heru (pseudonym), one of my informants from Surabaya, as he represents many other majority members of Banser who has 
uncertain jobs, uncertain income for their families, and uncertain 'future' of their children, once said:

"Saya di Banser tidak mencari keuntungan, bangkrut iya, tapi sepisan aku golek sedulur sing akeh, pindo aku pengen ngurangi dosa lewat berkahe pak Kyai, melu ngrasakke dadi santrine Mbah Hasyim. Aku pernah sakit nganti wis arep mati, diwacakke surat Yasin, ndilalah mari, sejak kuwi aku mandeg ngombe." ("I am not looking for material benefits from Banser, it's indeed makes me bankrupt, but first I am looking for a brotherhood as many as possible, and secondly I want to atone for my sins through a blessing from kyai, having an experience of becoming santri of Mbah Hasyim. I had a near-fatal sickness, but suddenly with the permission of God, I finally got recovered from it after I got healing prayers from kyai, and since then I promised to myself to stop drinking [alcohol]").

By using the narrative of Jihād Fì Sabilillāh Resolution 1945, they build a personal as well as collective commitment to become santri (pupil or follower) of KH Hasyim. By doing so, considering the fact that the majority of Banser members are coming from lower social and economic status, joining the group offers them a bigger chance of getting higher hierarchy (upward mobility) in local social and religious standards. Through the calling of jihad, and the fact that the nature of Banser's activities is based on the use of physical force, they usually protect themselves using specific physical training and for many members they equip their body and their belongings with what it is locally known as jimat (derived from Arabic word, azimah means strong firm or solid), a sacred thing (usually consists of Arabic handwritings) from Kyai or senior members and is believed to have a supranatural energy that can be used by the owners for many different purposes.

In order to get a power and azimah, there are several steps should be followed since the early stage of recruitment process, where I also engaged with Banser's Diklat Tingkat Dasar/DTD (the basic training) in Yogyakarta, they are not only trained with 
a military-based training but are also provided with a 'ritual' of ijazah (a method of transferring power of invulnerability from Pak Kyai or local ulama to all new members). In doing so, those new members are asked to take off clothes (sometimes they are left fully naked in a specific place in the dark night, or replaced by a white uniform just like they perform Hajj in Mecca). Then, they are guided by ulama to line up like soldiers (either in a standing or sitting position), to close their eyes by holding hands to each other, to recite specific texts in Quran or Hadith for specific number of repetitions (usually in odd number) combined with Javanese 'mantra'.

At the end of the ritual, they call it with many different local terms, such as ilmu Al Haddid or Inti Besi (the iron core), Asma' Wojo Tuwo (the "magic" of old iron), Susuk Loloh Baja, Susuk Loloh Gotri, Susuk Baja Gaib, Rujak Sewu, Aji Wojo Keramat, or any other name referring to the magic power of "sacred iron". A pot of water which has been purified with specific mantra is a must, hundreds of telur ayam kampung (free-range chicken eggs), a basket of pipit bananas (a small size one), misik oil from the deer sweat), forest honey, a bottle of liquid mercury, and a bag of buckshot. Although these tools vary between regions, the method is quite uniform. Then, one by one, an "extreme show" must be followed. They are required to swallow the whole egg with its shell, or putting odd amounts of buckshot (from 3-77 pieces depending on the braveness) on the chewed banana and then swallowed them together, or the lightest one is putting liquid mercury inside the whole banana and hen eat them together. The final step is a demonstration, started with the Kyai stabbing a sharp machete into his own arm, leg, stomach, and of course his neck. Several trainees are then asked to come forward trying the same simulation as they had seen from their master. The "magic" is real in their eyes, as nothing happened and all are 
immune from the machete (and in the old era, they were also tested by a bullet fire).

This aspiration, in fact, is not only echoed locally, but also manifested in national level. During my fieldwork, there was a massive nation-wide event of Kirab Satu Negeri (GP-Ansor's One Nation Parade) in October 2018 (in which I engaged with this specific activity since the initial meeting in Jakarta to all the way from Surabaya to Yogyakarta). Started in September $16^{\text {th }}$ from five different outermost areas of Indonesian state (Sabang in the western edge of Sumatra, Merauke in the most eastern part, Nunukan and Miangas in the northern most area, and Rote in the southernmost part), they tried to convince the public that the growing incidents of extremism, terrorism, radicalism, intolerance (including khilafahism) are just coming to the fore, and they encourage people to do real actions to prevent and to fight with them. All the way around the paramilitary parade of Banser was intended to promote what they call "menguatkan tali kebangsaaan" (tightening nationalism) through a slogan of "Banser-NU, Pancasila-Jaya, and NKRI Harga Mati”, as well as a way of explicitly irritating their opposing groups by showing a 'parade of power' and a commitment of contextualizing jihad into the a concrete form of a 'statehood religiosity'.

This parade was also intended to the global audiences by hosting the $2^{\text {nd }}$ Global Unity Forum ${ }^{3}$ in October 25-26 in Yogyakarta. The two-days of international conference in collaboration with Bayt Arrahmah ${ }^{4}$ (a US based Sunni Islam organization) aimed to addressing the main topic of "Weaponization of Religion" as currently occurring in many different parts of the world. Attended by Muslim, Christian, Hindu, Buddhist and Jewish leaders from US, Europe, and Asia,

\footnotetext{
${ }^{3}$ This was the second forum after the first one held in Jakarta in 2016.

${ }^{4}$ http://baytarrahmah.org
} 
they promoted to the world about the values and the practices of Islam Nusantara in Indonesia and resulted GP Ansor's Declaration of Humanitarian Islam to build a global awareness and to stop the weaponization of religion for economic and political purposes. A document called "Seruan Nusantara" (Nusantara Statement) written in four different languages was signed by all of the participants, and it said:

"We call upon people of goodwill of very faith and nation to join in building a global consensus to prevent the political weaponization of Islam, whether by Muslims or Non-Muslims, and to curtail the spread of communal hatred by fostering the emergence of a truly just and harmonious world order, founded upon respect for equal rights and dignity of every human being”.

It was an optimistic aspiration to the global audiences concerning to what religious tolerance should look like and how to deal with that in practice at the grassroot level. As the campaign of Islam Nusantara are currently enlarged by hundreds of international branches of NU in many different countries through academic seminars, workshops, discussions, and cultural missions (such as musical performance held in Europe last year), and more specifically recruitment and regeneration process of Banser has been expanded internationally (in South Korea, Hongkong, Taiwan, Malaysia, and in the Netherland has been recommended by the last branch meeting of PCINU), it is clear that paramilitary troops of GP Ansor-Banser soon becoming a citizen of a "global village" promoting Indonesian version of moderate Islam. Interestingly, some Banser members I met in South Korea also believe in jimat, use it, and teach other members to have it.

Jamaah Maiyah has different interpretation toward jihad. While the majority discourses of jihad is subjected to fight other opposing groups that are threatening, hostiling, or harming 
through physical violence (even though other groups also use the narrative of jihad), Jamaah Maiyah take seriously to a position that the highest level of jihad is jihadunnafs (a 'struggle', a 'striving', or a 'war' against the self). The narrative of "jabatan tertinggi adalah menjadi diri sendiri" (becoming yourself in the highest rank or position you can achieve). In this context, they believe that producing "new self" seriously is the ultimate goal in jihad because the self is the main agency who creates groups, social system and any other entities that are potentially conflicting each other when they face different interpretations and different interests. Within this paradigm, they call themselves as an organisme (organism) (instead of organisasi or Ormassocial or religious organization) working based on the function and the natural law, and is not based on the structure and the state law (like Banser and other groups).

This vision cannot be separated with the fact that Jamaah Maiyah is growing after the reform movement, in which Cak Nun was one of the 9 tokoh reformasi (reform figures) who engaged the critical processes of democratic transition, and was initially intended to respond to the failure of cita-cita reformasi (the refom agenda). The imagined new democratic state, as it was proposed by several reform figures, has never been achieved because what happened after the reform movement was what they call "Soehartoization", an authoritarian turn from centralized into decentralized corruption, and from reformasi into ref-Ormas-i. From this point of view, they come up to the idea that the main "enemies" and security threats for them and for the society are misunderstanding and misinterpretation within people's way of thinking that caused mismanagement and misbehavior within individual and social structure in society.

Accordingly, ndandani Indonesia (Javanese: 'fixing' Indonesia), for them, should be firstly based on correcting, repairing, 
or adjusting the way of thinking. Security or insecurity, in this context, is only an impact or a result of what is driven by the way how people think. In their perspective, everybody should be aware of "the need for training" on how people think and act properly in the society. The state system and its political contestation (including the rise of Ormas after the reform), in this case, has failed to carry out this mandate. Maiyah movement, then, has been trying to address this gap through the first step of what they call tadabbur, meaning the thematic and contextual interpretation of religious texts either from the Quran and Hadith or any other religious resources (instead of using tafsir: interpretation of religious texts that is hard to be understood in the grassroots level). Maiyahan and Sinau Bareng, in this context, have been trying to create an enabling 'training environment' by rejecting any social and religious segregations (including gender and patron-client based social structure). The more often they do tadabbur and they share knowledge and experience among Jamaah Maiyah (through Maiyahan and Sinau Bareng consist of discussion, workshops, and thematic gatherings), the higher skill of understanding, tolerance, and problem solving they get. Arifudin (pseudonym), a Maiyah activist of Bangbangwetan in Surabaya gives an interesting point of view about tadabbur:

“...after a decade of studying in pesantren, I just understood the concept of tadabbur clearly in this forum (Maiyah forum), especially the analogy of tadabbur as Cak Nun illustrated, with 'dubur' (rectum), suggesting that 'what comes out is the product of what enters'. it really deconstructs my understanding of the interpretation of religious texts which I have been wrongly understood" (Interview with Arifudin, December 6, 2018).

By doing so, after two decades of such intensive movements, there have been common discourses creating new individual and social sovereignty, new social system themselves that is not depending on the state support, Ormas, or any other 
socio-religious institution, but based on Maiyah values they created. In terms of organization, they call kesadaran organisme Maiyah (literally consciousness of Maiyah organism) derived from Islamic Sufism and it consists of four main components: Dzat (substance), means the source of idea, knowledge, and vision; Sifat (trait or character), means those who manage and act as a 'processor' of the ideas, knowledge, and visions; Isim (intermediary), means the transformers; and Jasad (body), means the implementors, operators, or the executor of Maiyah values. In the organizational structure of Maiyah, these components are applied into four main categories based of functional purposes. In the highest position, there is Marja' Maiyah (Maiyah references) consists of Cak Nun in Yogyakarta, Cak Fuad in East Java, and Syeikh Nursomad Kamba in Jakarta. Then, there are senior figures of Maiyah activists in Progress Management in Yogyakarta led by Toto Raharjo (the think tank) and Cak Zaky (Cak Nun's brother, the manager) and it is responsible for all Cak Nun's activities. In an equal position with Progress, there is Community Leader led by Sabrang Mowo Damar Panuluh (Cak Nun's Son) as a result of national Maiyah meeting. Under community leader's coordination, there are three different 'team leaders' who are in charge for strategic and planning issues, community coordination, and digital media communication. These team leaders are responsible for coordinating Maiyah activities which are divided into several regions and each region has at least one coordinator.

Among Jamaah Maiyah, there have been familiar idioms of orang maiyah (the people of Maiyah), majlis masyarakat maiyah (maiyah community), pejalan Maiyah (Maiyah travelers), rumah Maiyah (house of Maiyah) simpul Maiyah (maiyah nodes), lingkar Maiyah (Maiyah circles), universitas Maiyah (Maiyah university), negeri Maiyah (Maiyah nation), 
ijazah Maiyah (Maiyah 'mantra'), Silatnas Maiyah (National conference of Maiyah) in which I engaged the last event last year in Surabaya with a very optimistic topic they call "Blueprint Peradaban Masa Depan" (Blueprint of the Future Civilization). They are currently also finalizing the draft of Piagam Maiyah (Maiyah charter, a concept adopted from Piagam Madinah (Charter of Medina, the Constitution of Medina which consists of 47 articles or clauses arranged by the people of Medina together with immigrants from Mecca shortly after the arrival of the prophet in $622 \mathrm{CE}$ or the first year in Islamic calendar, with the supervision and consultation of the prophet). Most recently, in respond to the situation of national political polarization impacted by presidential election, they offer a new ‘jimat Maiyah' (azimah Maiyah) called Amar Maiyah (special prayers to prevent destruction) which massively performed by all Maiyah community across the country and globally. Within this new imagined community, a slogan of "Indonesia Bagian dari Desa Saya" (Indonesia is part of my village), a book written by Cak Nun in the early period of Padhangmbulan gathering (the first Maiyah forum), is realized, and it has currently been widely symbolized by peci Maiyah (Maiyah cap), a Sufi-like cap with red and white colors (similar with the color of Indonesian flag), the only 'material culture' representing Maiyah unity.

Jimat (azimah) in Maiyah community is not based on a combination between spiritual and physical power different as what Banser has, but it is derived from a combination between love and spirituality. One of the many practices of getting jimat from Maiyah forums is what it is known as Suwuk in Javanese society. It is a common practice of traditional treatment method rooted from the old period of Javanese civilization using shaman's mantras and different types of prayers based on the purposes which put in a glass of water. As it is commonly 
used for the healing process of both physical and non-physical illnesses, in Maiyah community it is used for ngobati pikir lan ati (for the treatment of mind and soul). In order to get this, many people usually bring a bottle or two of mineral water to Maiyahan or Sinau Bareng. At the end of the event, there is always a long queue of people willing to shake hand with Cak Nun and other Maiyah figures in the stage, and those who aim to get suwuk from Cak Nun. And what Cak Nun say about this practice, he usually tell jamaah (the audiences): "it is not because of me, it is because you come here with love and with a full of submission to ask God to help you, and we ask Him and praise the prophet Muhammad together in order to grant all our prayers, so we believe that God will do so". Interestingly, I also found this practice in the US, in Europe, Australia, South Korea, Egypt, and in many other countries wherever Cak Nun and other charismatic figures visit those countries and held a meeting with Indonesian communities.

Like Banser's aspiration of becoming santri of Mbah Hasyim has become a common reason for joining the group, it is also commonly expressed by Maiyah activists (as they are reluctant to be called Maiyah followers or the followers of Cak Nun), is becoming santri of Mbah Nun (Cak Nun). In this context, while Banser has a motive of experiencing the spirit of NU's Jihad Resolution for defending the state, Jamaah Maiyah has an intention to feel some of the core values of Maiyah, as Cak Nun frequently says:

"menjadi manusia ruang yang mampu menampung semua golongan" (becoming a man of 'space' who has an ability to accommodate all groups), or Islam itu kata kerja, bukan identitas, sehingga outputnya adalah menyelamatkan orang lain (Islam is a verb, not an identity, so that the consequence is saving others), or "jika tidak bisa menjadi bagian dari solusi, minimal tidak menambah masalah di masyarakat, itulah prinsip hidup orang Maiyah" (if becoming part of the solution of 
societal problems is impossible, then at least, not adding more problems, that is the life principle of Maiyah).

In applying these principles, in Yogyakarta, for example, two Maiyah activists from NU and Muhammadiyah established Nahdlatul Muhammadiyin (NM), a study group led by a combination of both NU and Muhammadiyah local senior figures to bridge classical debates between the two groups about different interpretations and daily religious practices. These principles also applied by Cak Nun and Kiaikanjeng during their performances on the global arenas. In 2002, their tour to six Egyptian provinces performing a 'gamelan version' of the songs by Ummi Kultsum (a legendary Egyptian singer) was an eye opener for the Muslim communities in Egypt on how Islam, traditional music from Java, and Arabic song were harmonized by a group of people who do not speak Arabic at all. During the second tour to UK in 2005, Gordon Brown who made a speech expressed his amazed and said that "the diversity of nuances and the cohesion of global pluralism reflected by the pattern of arrangements and the sound of the music of Kiaikanjeng aptly picture the ideals we are fighting for and which we should achieve in the world of today and of tomorrow" (Betts 2016). In Italy 2005, even though almost all members of Kiaikanjeng have no official musical background (musical expertise through training) or higher academic background but use only their Maiyah spirit and loyalty to the values of șalawat, and they were called 'Complimente, Complimente Maestro, Grazia Maestro!'s (Betts 2006). In 2008, they were also invited by the Protestant Church in The Netherlands for the intercultural and interreligious project of nine citis tour entitled Voices and Visions: An Indonesian Muslim Poet Sings a Multifaceted Society following

\footnotetext{
${ }^{5}$ A special recognition awarded by Classical musicians in Italy when Kiakanjeng performed in three different cities, including in Rome at the moment of the passing of the Pope John Paul II on April 2005.
} 
the provocative film Fitna made by Geert Wilders. Other tours in Australia (2003, 2008), Scotland (2005), Germany (2005), Finland (2006), Malaysia (2005, 2007), Abu Dhabi (2008), Morocco (2013), and in other countries were not only reflected interreligious and intercultural dialogues but also brought people together to appreciate the differences in many dimensions of life and promoted mutual understanding among human being. This is how Cak Nun interprets Indonesian Bhineka Tinggal Ika (the state principle of 'unity in diversity') to be promoted to the world.

\section{Concluding Remarks}

The nature of 'bottom-up governance' developed and campaigned by Banser and Jamaah Maiyah, in which the one is shaped in a more practical way of political approach, and the other is denoted in a more aesthetical manner of socio-religious movement may shed light two different facets of theoretical and empirical shift toward social harmony within the era of insecurity and uncertainty in post-democratic transition.

First, the discourses and the conceptual drivers they use, derived from both religious norms (the moment of hijrah of the prophet Muhammad and the interpretation of jihad in Islam), and local socio-cultural values (perceived imaginary of a nationstate of Indonesia) aspire deconstructive perspectives toward hegemonic Western-centric way of thinking, knowledge, and discussions about global governance, nationhood or nationalism, democracy, and civil society.

Second, the empirical, material, and practical conditions that navigate the production and reproduction of the local-nationalglobal imagining of community may also offer a new puzzle for re-imagining and re-understanding the mainstream traditions on how to maintain social cohesion and to create social order in society. 
The role of non-state actors, based on the cases of Banser and Jamaah Maiyah, along with the unbelievable use of internet for a wide range of purposes in the digital age, and the utilization of social media as means for terrorist recruitment, violent religious indoctrination, and showcase of violence and extremism, referring to McChesney's (2013) notion of 'digital disconnect' in understanding how capitalism is turning the internet against democracy, has reflected new shared social imaginaries. In this respect, as socio-religious movements performed by both Banser and Jamaah Maiyah are also introducing and envisioning new kinds of perspectives of the state, creating new consciousness of nationalism, and dealing with security provision, they clearly has blurred what Anderson (1983) calls as "imagined community", more specifically with the premise he proposed that nationalism is built through two main channels: the 'institutionalization of identity' (involving the discussions of census, map, and museum as material artifacts for the production and reproduction of nations) and 'print capitalism' (using newspapers and novels as narrative structures for creating vernacular literatures).

In a broader context, this has also compelled the tradition of scholar-activism to rethink about the death of print capitalism that is radically transformed the ways how people introduce new kinds of more complex narrative structures through different forms of language, literature, and national identity. Within this newly society arrangement, where there are no clear supreme exemplars of the infrastructure of national imaginaries, the institutionalization of identity is currently recognized, produced, reproduced, and reinforced by new cultural constructions involving multi-actor and multi-interest parties, the contestation of politics of identity, the reinterpretation of the role of religion, and the remaining state-centered effort of governing society have intertwined a new form of imagined communities, that is 'out 
of the state' governance dealing with on-the-ground problem solving throughout the global village.

\section{Bibliography}

Abrahamsen, Rita, and Michael C. Williams. 2009. "Security Beyond the State: Global Security Assemblages in International Politics." International Political Sociology 3 (1): 1-17. https://doi.org/10.1111/j.1749-5687.2008.00060.x.

Anam, Choirul. 1996. Gerak Langkah Pemuda Ansor: Seputar Sejarah Kelahiran. Jakarta: Duta Aksara Mulia.

Anderson, Benedict. 1983. Imagined Communities: Reflections on the Origin and Spread of Nationalism. New York: Verso.

Bakker, Laurens. 2015. "Illegality for the General Good? Vigilantism and Social Responsibility in Contemporary Indonesia." Critique of Anthropology 35 (1): 78-93. https://doi. org/10.1177/0308275X14557092.

Bayat, Asef. 2005. "Islamism and Social Movement Theory." Third World Quarterly 26 (6): 891-908. https://doi. org/10.1080/01436590500089240.

Beittinger-Lee, Verena. 2010. (Un)Civil Society and Political Change in Indonesia: A Contested Arena. New York: Routledge.

Betts, Ian L. 2006. Jalan Sunyi Emha. Jakarta: Kompas Gramedia.

2016. "The Silent Pilgrimage: Then, Now and From Here to Where? Prospects and Opportunities for the Maiyah in A Globalised World.” Kenduricinta.Com. 2016. http:// kenduricinta.com/v5/the-silent-pilgrimage-then-now-andfrom-here-to-where-prospects-and-opportunities-for-themaiyah-in-a-globalised-world/.

Botz, Dan La. 2001. Made in Indonesia: Indonesian Workers Since Suharto. Cambridge, Massachusetts: South End Press.

Daniels, Timothy. 2009. Islamic Spectrum in Java: Anthropology and Cultural History in Asia and the Indo-Pacific. New York: Ashgate Publishing. 
Denney, Lisa. 2012. Non-State Security and Justice in Fragile States: Lessons from Sierra Leone. ODI Briefing Paper. Vol. 73. London: Overseas Development Institute.

Geertz, Clifford. 1996. "Religion as a Cultural System.” In Anthropological Approaches to the Study of Religion. London: Tavistock.

Gilani, Ijaz, Heald Johnny, and Marita Carballo. 2018. "Religion Prevails in the World." Gallup International. 2018.

Hefner, Robert W. 2013. "The Study of Religious Freedom in Indonesia." Review of Faith and International Affairs 11 (2): 18-27. https://doi.org/10.1080/15570274.2013.808038.

Kamba, Nursamad. 2015. "Manusia Ihsan Dan Esensi Kekhalifahan.” Sufinews.Com. 2015. http://www.sufinews.com/ manusia-ihsan-dan-esensi-ke-khalifahan/.

_. 2018. "Maiyah Dan Jalan Kenabian.” Buletin Maiyah Jawa Timu, 2018.

Kleden, Ignas. 2003. "Religion, Peace and Conflict.” The Jakarta Post, 2003.

Krause, Peter. 2013. "The Political Effectiveness of Non-State Violence: A Two-Level Framework to Transform a Deceptive Debate." Security Studies 22 (2): 259-94. https://doi.or $\mathrm{g} / 10.1080 / 09636412.2013 .786914$.

Lipschutz, R. D. 2009. The Constitution of Imperium. Boulder: Paradigm.

McChesney, Robert W. 2013. Digital Disconnect: How Capitalism Is Turning the Internet Against Democracy. New York: New Pess.

Mietzner, Marcus. 2002. "Politics of Engagement: The Indonesian Armed Forces, Is-Lamic Extremism, and the War on Terror." Brown Journal of World Affairs 9 (1): 71-84.

Nadjib, Emha Ainun. 2016. Demokrasi La Roiba Fih. Jakarta: Kompas Gramedia.

Nordholt, H. Schulte. 2016. "From Contest State to Patronage Democracy: The Lounge Durée of Clientelism in Indonesia." In Environment, Trade and Society in Southeast Asia, 
edited by D. Henley and H. Schulte Nordholt, 166-80. Leiden: Brill.

Salim, Hairus. 2004. Kelompok Paramiliter NU. Jakarta: LKiS.

Schirch, Lisa. 2015. "Ritual, Religion, and Peacebuilding." In The Oxford Handbook of Religion, Conflict, and Peacebuilding, edited by Atalia Omer, 516-40. Oxford: Oxford University Press.

Sternberg, R. J. 1988. The Triangle of Love. New York: Basic.

Sumuranje, Nuhwan ML. 2013. Cinta Sejati Emha Buat Pak Harto. Yogyakarta: Kaukaba Dipantara.

Telle, Kari. 2013. "Vigilante Citizenship: Sovereign Practices and the Politics of Insult in Indonesia." Bijdragen Tot de Taal-, Land-En Volkenkunde / Journal of the Humanities and Social Sciences of Southeast Asia 169 (2-3): 183-212. https://doi.org/10.1163/22134379-12340029.

Watts, Fraser, and Roger Bretherton. 2017. “'Religion' Is Complex and Diverse." Religion, Brain and Behavior 7 (4): 37882. https://doi.org/10.1080/2153599X.2016.1249930.

Widiyanto, Asfa. 2016. Religious Authority and the Prospects for Religious Pluralism in Indonesia: The Role of Traditionalist Muslim Scholars. Zurich: Lit Verlag GmbH \& Co. KG Wien.

Wildman, Wesley J. 2011. “The Religious Violence Project.” In $A$ Report to the 2010-2011 Edition of the Boston Uni-Versity Religion Fellows Program. Boston: Boston University and the Institute for the Biocultural Study of Religion.

Wilson, Lee. 2017. "How Critical Can Critical Be? Contesting Security in Indonesia." Critical Studies on Security 5 (3): 302-16. https://doi.org/10.1080/21624887.2018.1424985 